CENDEKIA, Vol. 11, No. 2, Oktober 2017

p ISSN: 1978 2098; e ISSN: 2407 8557

Http://cendekia.pusatbahasa.or.id; Email: cendekiaoslo@gmail.com

Center of Language and Culture Studies, Surakarta, Indonesia

Yunastutik, Games. 2017. Peningkatan Prestasi Belajar Matematika Melalui

Pembelajaran Behavioristik pada Siswa SMPN 1 Karangploso.

Cendekia, (2017), 11(2): 207 220.

\title{
PENINGKATAN PRESTASI BELAJAR MATEMATIKA MELALUI PEMBELAJARAN BEHAVIORISTIK PADA SISWA SMPN 1 KARANGPLOSO
}

\author{
Games Yunastutik \\ SMP Negeri 1 Karangploso \\ Jalan PB. Sudirman 49 Karangploso \\ Email: gimyunastutik@gmail.com
}

\begin{abstract}
This two cycle classroom research aims to improve student achievement in mathematics through behavioristic learning for students of class VII SMPN 1 Karangploso. In each cycle, the researcher applied: planning, acting, observing and replection as the research procedure. Data of this study were students' interactions using behavior learning. Data were analyzed using descriptive statistics. The results showed that in the pre-cycle students' mean score was 82 . The mean score increased into 83 and 86 respectively in the cycle I and cycle II. This means the achievement on mathematic lesson using the behavioristic is quite good as indicated that the attainment is $\geq 75 \%$. In addition, students activities during the learning process also increased based on observations of the first cycle and the cycle two, admitting that behavioristic learning evidently improve accomplishment in mathematics for the seventh graders of SMPN 1 Karangploso.
\end{abstract}

Keywords: learning achievement, learning behavioristic, mathematics

Prestasi belajar merupakan hasil belajar siswa setelah melalui proses pembelajaran. Suryabrata (2006:297) menjelaskan bahwa prestasi adalah nilai perumusan terakhir yang dapat diberikan oleh guru mengenai kemajuan/hasil belajar siswa selama masa tertentu. Prestasi tersebut dilihat dari hasil tes yang dapat digunakan guru sebagai bahan refleksi keberhasilan proses pembelajaran.

Prestasi belajar dapat dibangun melalui penumbuhan motivasi belajar. Motivasi merupakan keseluruhan daya penggerak di dalam diri siswa yang menimbulkan kegiatan belajar, yang menjamin kelangsungan dari kegiatan belajar dan memberikan arah pada kegiatan belajar sehingga tujuan yang dikehendaki oleh subjek belajar itu dapat tercapai (Sardiman, 2000). Siswa yang memiliki motivasi belajar bergantung pada aktivitas pembelajaran yang memiliki isi menarik dan menyenangkan. Intinya, motivasi belajar melibatkan tujuan-tujuan belajar dan strategi yang berkaitan dalam mencapai tujuan belajar tersebut (Brophy, 2004).

Berdasarkan pengamatan yang dilakukan peneliti, proses pembelajaran Matematika mengalami beberapa kendala yakni kesulitan siswa dalam memahami materi perbandingan. Padahal, pemahaman dan penguasaan 
CENDEKIA, Vol. 11, No. 2, Oktober 2017

p ISSN: 1978 2098; e ISSN: 2407 8557

Http://cendekia.pusatbahasa.or.id; Email: cendekiaoslo@gmail.com Center of Language and Culture Studies, Surakarta, Indonesia

Yunastutik, Games. 2017. Peningkatan Prestasi Belajar Matematika Melalui Pembelajaran Behavioristik pada Siswa SMPN 1 Karangploso.

Cendekia, (2017), 11(2): 207 220.

Matematika merupakan modal utama dalam komunikasi dan kegiatan pembelajaran. Peneliti fokus pada materi perbandingan dikarenakan siswa kelas VII terutama kelas VII D masih rancu dalam membedakan perbandingan yang senilai dan perbandingan yang berbalik nilai. Hal tersebut menyebabkan siswa sering keliru dalam menerapkan rumus yang digunakan dalam mencari penyelesaiannya. Salah satu contoh ada soal berikut.

Sebuah rak buku dapat memuat 36 buku yang tebalnya 8 milimeter. Berapa buku yang dapat ditaruh di rak tersebut jika tiap buku tebalnya 12 milimeter? Dari soal ini ada siswa yang beranggapan bahwa soal tersebut merupakan soal perbandingan senilai, padahal soal tersebut merupakan soal dari perbandingan berbalik nilai. Siswa salah dalam menganalisis soal dikarenakan kurang teliti dalam memahami soal. Selain itu, ketika ada kuis atau ulangan harian waktu yang tersisa dalam mengerjakan soal tinggal sedikit sehingga siswa kebingungan dan asal menjawab. Inilah salah satu penyebab siswa sering salah dalam membedakan soal perbandingan senilai maupun perbandingan berbalik nilai. Skor rata-rata untuk materi sebelumnya dapat dilihat pada tabel 1 .

Tabel 1 Rata-rata Prestasi Awal (sebelum tindakan)

\begin{tabular}{|l|c|}
\hline & Prestasi Awal \\
\hline Nilai rata - rata & 82,05 \\
\hline SKM (Standart Kelulusan Minimal) & 38 \\
\hline Ketuntasan klasikal95 \% & $86,43 \%$ \\
\hline Jumlah siswa & 39 siswa \\
\hline
\end{tabular}

Dari tabel di atas dapat terlihat bahwa skor rata-rata prestasi siswa sebelum dikenai pembelajaran kontekstual, yaitu sebesar 82,05. Ketuntasan belajar yang dapat dicapai dengan SKM (Standart Kelulusan Minimumnya adalah 75) sebesar 86,43\% siswa yang mencapai SKM sehingga ketuntasan klasikal dengan landasan minimal $95 \%$ dalam kelas belum bisa tercapai terbukti dari $86,43 \%$ siswa yang mencapai SKM. Hal ini dikarenakan masih ada siswa yang belum bisa mencapai SKM. Berdasarkan hal tersebut peneliti berusaha agar siswa kelas VII D bisa mencapai SKM.

Rendahnya nilai prestasi belajar Matematika siswa kelas VII D SMP Negeri 1 Karangploso dipengaruhi oleh lima faktor. Lima faktor tersebut yaitu (1) proses pembelajaran, (2) siswa, (3) guru, (4) lingkungan kelas, dan (5) materi pelajaran. Proses pembelajaran Matematika belum menarik bahkan saat berlangsung pembelajaran masih berpusat pada guru dan belum melibatkan keaktifan siswa. Pembelajaran masih menggunakan gaya belajar ceramah dan sedikit penjelasan. Faktor siswa merupakan faktor kedua yang mempengaruhi rendahnya prestasi belajar Matematika. Siswa kelas VII D cenderung pasif saat mengikuti pembelajaran Matematika. Sebagian siswa duduk diam mendengarkan guru dan sebagian siswa asyik bermain dan ngobrol dengan 
CENDEKIA, Vol. 11, No. 2, Oktober 2017

p ISSN: 1978 2098; e ISSN: 2407 8557

Http://cendekia.pusatbahasa.or.id; Email: cendekiaoslo@gmail.com

Center of Language and Culture Studies, Surakarta, Indonesia

Yunastutik, Games. 2017. Peningkatan Prestasi Belajar Matematika Melalui

Pembelajaran Behavioristik pada Siswa SMPN 1 Karangploso.

Cendekia, (2017), 11(2): 207 220.

temannya. Siswa malas mengikuti pembelajaran, karena menganggap materi Matematika sangat sulit dipahami, dan menuntut mereka untuk teliti dalam berhitung. Dilihat dari faktor guru diantaranya tentang metode dan pembelajaran yang diterapkan. Guru belum menerapkan pembelajaran yang menarik. Guru cenderung mendominasi kegiatan belajar dengan metode ceramah. Lingkungan kelas turut berpengaruh terhadap prestasi belajar. Kelas VII D terlalu gaduh ketika guru memberikan materi sehingga informasi tidak tersampaikan secara maksimal. Segi materi pelajaran pun ikut mempengaruhi prestasi belajar Matematika.

Pada dasarnya masalah timbul karena adanya ketidaksesuaian antara harapan dan kenyataan yang ada. Rendahnya tingkat penguasaan siswa di dalam kegiatan belajar mengajar merupakan indikasi rendahnya kualitas pembelajaran di samping juga faktor-faktor pada diri anak yang berasal dari luar siswa. Melalui proses pembelajaran yang terencana dengan metode-metode yang sesuai, maka rendahnya hasil belajar siswa dapat ditingkatkan. Oleh karena itu, penguasaan dan pemahaman siswa terkait materi perbandingan perlu ditingkatkan dengan cara menerapkan metode pembelajaran yang membimbing siswa aktif dan melalui pengalaman belajar. Oleh karena itu, guru menerapkan pembelajaran behavioristik untuk meningkatkan prestasi belajar siswa.

Behavioristik dalam pembelajaran merupakan upaya membentuk tingkah laku yang diinginkan. Menurut Watson (dalam Uno, 2006:7) behavioristik menekankan stimulus respons yang harus berbentuk tingkah laku yang bisa diamati dan tidak memikirkan hal-hal yang tidak bisa diukur. Pembelajaran behavioristik sering disebut juga dengan pembelajaran stimulus respons. Tingkah laku manusia dikendalikan oleh ganjaran (reward) atau penguatan dari lingkungan yang menjadi salah satu komponen dalam teori ini. Tingkah laku peserta didik merupakan reaksi-reaksi terhadap lingkungan dan bahwa segenap tingkah laku merupakan hasil belajar.

Behavioristik merupakan teori mengenai tingkah laku seseorang yang berfungsi untuk menjaga kelangsungan hidup berupa pemenuhan kebutuhan. Menurut Guthrie (dalam Uno, 2006:8) mengungkapkan bahwa teori belajar behavioristik merupakan kaitan asosiatif antara stimulus tertentu dan respons tertentu. Diperlukan pemberian stimulus yang sering agar respons lebih kuat. Berbeda dengan pendapat-pendapat di atas, menurut Skiner (dalam Dalyono 2009:32) behavioristik menganggap "reward" atau penguatan sebagai faktor terpenting dalam proses belajar. Hubungan stimulus dan respons menjelaskan perubahan tingkah laku peserta didik dalam pembelajaran.

Pembelajaran behavioristik bisa meningkatkan mutu pembelajaran jika dikenalkan kembali penerapannya dalam pembelajaran. Berdasarkan komponennya, teori ini relevan jika digunakan dalam pembelajaran sekarang ini. Penerapan teori behavioristik sekarang ini mudah sekali ditemukan di sekolah. Hal ini dikarenakan mudahnya penerapan teori ini untuk meningkatkan kualitas peserta didik. Salah satu contoh penerapannya yaitu misalnya guru memberikan contoh cara menyelesaikan soal cerita dengan benar. Setelah itu peserta didik bisa membuat soal cerita tentunya dengan kasus maupun angka yang berbeda dari guru. Dalam pembelajaran terkadang 
CENDEKIA, Vol. 11, No. 2, Oktober 2017

p ISSN: 1978 2098; e ISSN: 2407 8557

Http://cendekia.pusatbahasa.or.id; Email: cendekiaoslo@gmail.com

Center of Language and Culture Studies, Surakarta, Indonesia

Yunastutik, Games. 2017. Peningkatan Prestasi Belajar Matematika Melalui

Pembelajaran Behavioristik pada Siswa SMPN 1 Karangploso.

Cendekia, (2017), 11(2): 207 220.

juga terjadi salah tafsir peserta didik dalam memahami soal atau pembelajaran yang dilakukan guru. Setelah pembelajaran tersebut guru memberikan penguatan lagi kepada peserta didik. Dengan demikian, peserta didik akan termotivasi dan akan terjadi perubahan perilaku peserta didik menjadi lebih baik. Perubahan perilaku tersebut yaitu peserta didik yang pada awalnya tidak mengetahui perilaku (behavioristik), nantinya akan mengerti. Peserta didik bisa menjelaskan, menggambarkan, dan mendeskripsikan hasil belajar setelah pembelajaran berlangsung.

Penelitian ini juga didasarkan pada dua penelitian. Penelitian Budiyono (1997) yang berjudul "Hubungan Antara Perilaku dengan Lingkungan" merupakan suatu kajian dari teori psikologi lingkungan membahas tentang psikologi lingkungan merupakan cabang psikologi yang mengkaji interelasi antara perilaku manusia dengan lingkungan alam dan lingkungan binaan. Dalam psikologi behavioristik, perilaku manusia muncul sebagai respons terhadap stimulus yang ada. Lingkungan merupakan stimulan dari suatu sumber informasi. Perilaku seseorang dalam lingkungan berhubungan dengan latar perilakunya atau behavior setting. Lingkungan sebagai behavior setting tidaklah netral, dalam arti bahwa bukanlah lingkungan yang menjadi setting tetapi bagaimana kelompok individu memakai lingkungan tersebut yang menjadi latar perilaku. Penting bagi seorang pendidik untuk membuat setting yang tepat mengenai lingkungan yang ada sehingga menjadi setting yang edukatif. Penciptaan setting ini tidak hanya bersifat fisik tetapi juga psikologis sehingga butuh proses dan kewibawaan edukatif.

Penelitian Astuti (2011) menunjukkan bahwa dalam pembelajaran menulis karangan narasi sangat diperlukan stimulus respons yang tepat. Perilaku (behavioristik) yang muncul dalam pembelajaran menulis karangan narasi di SMP Negeri 1 Taman Kabupaten Pemalang terdiri atas dua respons yaitu respons verbal dan respons nonverbal. Respons verbal yaitu perilaku yang muncul berupa tindakan yang dilakukan siswa yaitu siswa mengujarkan sesuatu atas stimulus yang diberikan oleh guru sebagai bentuk responsnya. Respons nonverbal ditunjukkan oleh siswa dengan diam, mengangguk, tersenyum, dan menulis. Karakteristik dari perilaku yang teridentifikasi diklasifikasikan menurut jenis responsnya. Dalam respons verbal teridentifikasi perilaku siswa antara lain menyebutkan, menjawab, bertanya, menyampaikan, menanggapi, dan mengomentari. Respons nonverbal yang teridentifikasi yaitu siswa mencatat, menyusun, dan mengubah penulisan yang salah berkaitan dengan menulis karangan narasi sesuai dengan stimulus dalam tiap-tiap tahap pembelajaran yang dilakukan. Berdasarkan hasil data dapat diketahui bahwa perilaku (behavioristik) yang diinginkan dalam tujuan pembelajaran dapat dicapai.

Pembelajaran Matematika pada materi perbandingan memerlukan strategi baru untuk meningkatkan prestasi belajar. Berdasarkan uraian tersebut, peneliti melakukan penelitian tindakan kelas untuk menerapkan pembelajaran behavioristik yang berjudul 
CENDEKIA, Vol. 11, No. 2, Oktober 2017

p ISSN: 1978 2098; e ISSN: 2407 8557

Http://cendekia.pusatbahasa.or.id; Email: cendekiaoslo@gmail.com

Center of Language and Culture Studies, Surakarta, Indonesia

Yunastutik, Games. 2017. Peningkatan Prestasi Belajar Matematika Melalui

Pembelajaran Behavioristik pada Siswa SMPN 1 Karangploso.

Cendekia, (2017), 11(2): 207 220.

"Peningkatan Prestasi Belajar Mata Pelajaran Matematika Melalui Pembelajaran Behavioristik pada Siswa Kelas VII SMP Negeri 1 Karangploso”.

\section{METODE}

Jenis penelitian ini menggunakan penelitian tindakan kelas. Penelitian tindakan dilakukan melalui dua siklus. Siklus-siklus tersebut meliputi beberapa tahap meliputi perencanaan, pelaksanaan, observasi/evaluasi, dan refleksi (Muyasa, 2013:70-73). Penelitian tindakan bertujuan untuk menyelesaikan masalah dengan menerapkan metode tertentu. Peneliti bertindak sebagai pengamat sekaligus pelaksana kegiatan. Sebagaimana Arikunto (2002) menjelaskan bahwa guru melakukan pengamatan terhadap diri sendiri ketika sedang melakukan tindakan. Oleh karena itu, peneliti berperan sebagai perencana, pelaksana, pengumpul data, penganalisis data, penafsir data, dan pada akhirnya peneliti menjadi pelapor hasil penelitian. Penelitian ini dilakukan di SMP Negeri 1 Karangploso. Subjek penelitian yaitu siswa kelas VII B SMP N 1 Karangploso tahun pelajaran 2013/2014 sebanyak 32 siswa yang terdiri dari 16 siswa dan 16 siswi. Sumber data diperoleh dari hasil tes, lembar observasi, dan lembar kerja siswa hasil diskusi kelompok.

Penelitian ini menggunakan teknik analisis deskriptif kualitatif, yaitu suatu metode penelitian yang bersifat menggambarkan kenyataan atau fakta sesuai dengan data yang diperoleh dengan tujuan untuk mengetahui prestasi belajar yang dicapai siswa juga untuk memperoleh respon siswa terhadap kegiatan pembelajaran serta aktivitas siswa selama proses pembelajaran. Analisis ini dihitung dengan menggunakan statistik sederhana dengan tahapan-tahapan, yaitu:

1. Daftar tabel dari jawaban lembar observasi

2. Menentukan skor jawaban

3. Data tentang hasil belajar (kognitif) siswa dihitung dengan menggunakan rumus:

$$
\text { Nilai Akhir }=\frac{\text { jumlah jawaban beaar }}{\text { jumlah jawaban salah }} \text { x } 100 \text { (Slamet dalam Fery, 2007:57) }
$$

4. Analisis Lembar observasi untuk mengetahui peningkatan prestasi belajar siswa. Kemudian dianalisis menggunakan analisis presentase. Untuk analisis presentase menggunakan rumus sebagai berikut:

$$
P=\frac{S}{N} \times 100 \% \quad \text { (Ali M. Dalam Fery, 2007:57) }
$$

Keterangan :

$P \quad:$ Persentase pelaksanaan setiap indikator

$S \quad$ : Jumlah skor perolehan untuk setiap indikator

$N \quad$ : Jumlah skor total

Dalam penelitian ini digunakan empat kategori yaitu : sangat aktif, aktif, kurang aktif, kurang aktif dan tidak aktif Siswa yang memiliki skor

$4 \quad$ : Untuk kategori aktif

3 : Untuk kategori cukup aktif

2 : Untuk kategori kurang aktif

1 : Untuk kategori tidak aktif 
Untuk menentukan berapa skor yang telah diperoleh oleh setiap siswa yang nantinya dapat dikategorikan dalam empat kategori di atas adalah dengan menggunakan rentang nilai yang didapat dari hasil tes yang telah dilakukan, seperti tampak pada tabel 2 .

Tabel 2. Kriteria rentangan skor

\begin{tabular}{|l|l|}
\hline Rentang Nilai & Skor yang didapat \\
\hline $91-100$ & 4 \\
\hline $86-90$ & 3 \\
\hline $81-85$ & 2 \\
\hline $75-80$ & 1 \\
\hline
\end{tabular}

5. Data ketuntasan belajar siswa dihitung dengan menggunakan rumus deskriptif presentase sebagai berikut:

Presentase $(\%)=\frac{n}{N} \times 100 \% \quad$ (Ali M. Dalam Fery, 2007:58)

Keterangan : $n:$ Jumlah skor yang diperoleh dari data

$N$ : Jumlah skor maksimal

6. Untuk ketuntasan hasil belajar

Ada dua kategori ketuntasan belajar yaitu secara perorangan dan secara klasikal. Berdasarkan petunjuk pelaksanaan belajar mengajar kurikulum 1994 (Depdikbud, 1994), yaitu seorang siswa telah tuntas belajar bila telah mencapai skor $75 \%$ atau nilai 75 , dan kelas disebut tuntas belajar bila di kelas tersebut terdapat $85 \%$ yang telah mencapai daya serap lebih dari atau sama dengan $75 \%$. Untuk menghitung persentase ketuntasan belajar digunakan rumus sebagai berikut:

$$
P=\sum \frac{\text { Stwa yang runtas bela jar }}{\text { Esiswa }} \times 100 \%
$$

Tahap-tahap kegiatan belajar mengajar (KBM) disesuaikan dengan rancangan awal penelitian meliputi perencanaan, tindakan, observasi, dan refleksi. Tahap tersebut dijabarkan sebagai berikut.

\section{Tahap Pratindakan}

Tahapan Pra PTK ini dilaksanakan sebelum rencana tindakan disusun. Kegiatan dilakukan dengan observasi sekolah, wawancara dengan guru lain, penelusuran permasalahan pembelajaran Matematika, dan penentuan subjek penelitian. Tahap ini juga dapat untuk menentukan strategi pembelajaran yang akan digunakan sebagai alternatif pemecahan masalah. Berdasarkan hasil pratindakan, peneliti menggunakan 
CENDEKIA, Vol. 11, No. 2, Oktober 2017

p ISSN: 1978 2098; e ISSN: 2407 8557

Http://cendekia.pusatbahasa.or.id; Email: cendekiaoslo@gmail.com

Center of Language and Culture Studies, Surakarta, Indonesia

Yunastutik, Games. 2017. Peningkatan Prestasi Belajar Matematika Melalui

Pembelajaran Behavioristik pada Siswa SMPN 1 Karangploso.

Cendekia, (2017), 11(2): 207 220.

pembelajaran behavioristik untuk meningkatkan prestasi belajar siswa dalam belajar Matematika.

\section{Perencanaan Tindakan}

Berdasarkan pada identifikasi masalah yang dilakukan pada tahap pra PTK, rencana tindakan disusun untuk menguji secara empiris hipotesis tindakan yang ditentukan. Rencana tindakan ini mencakup semua langkah tindakan secara rinci. Segala keperluan pelaksanaan PTK, mulai dari materi/bahan ajar, rencana pengajaran yang mencakup metode/ teknik mengajar, serta teknik atau instrumen observasi/ evaluasi, dipersiapkan dengan matang pada tahap perencanaan ini. Dalam tahap ini perlu juga diperhitungkan segala kendala yang mungkin timbul pada saat tahap implementasi berlangsung. Dengan melakukan antisipasi lebih dari diharapkan pelaksanaan PTK dapat berlangsung dengan baik sesuai dengan hipotesis yang telah ditentukan.

\section{Pelaksanaan Tindakan}

Tahap ini merupakan implementasi (pelaksanaan) dari semua rencana yang telah dibuat. Tahap ini, yang berlangsung di dalam kelas adalah realisasi dari segala teori pendidikan dan teknik mengajar yang telah disiapkan sebelumnya. Langkah-langkah yang dilakukan guru tentu saja mengacu pada kurikulum yang berlaku, dan hasilnya diharapkan berupa peningkatan efektivitas keterlibatan kolaborator sekedar untuk membantu si peneliti untuk dapat lebih mempertajam refleksi dan evaluasi yang dia lakukan terhadap apa yang terjadi dikelasnya sendiri. Dalam proses refleksi ini segala pengalaman, pengetahuan, dan teori pembelajaran yang dikuasai dan relevan.

\section{Pengamatan Tindakan}

Kegiatan observasi dilakukan bersamaan dengan pelaksanaan tindakan. Data yang dikumpulkan pada tahap ini berisi tentang pelaksanaan tindakan dan rencana yang sudah dibuat, serta dampaknya terhadap proses dan hasil intruksional yang dikumpulkan dengan alat bantu instrumen pengamatan yang dikembangkan oleh peneliti. Pada tahap ini perlu mempertimbangkan penggunaan beberapa jenis instrumen ukur penelitian guna kepentingan triangulasi data. Dalam melaksanakan observasi dan evaluasi, guru tidak harus bekerja sendiri. Dalam tahap observasi ini guru bisa dibantu oleh pengamat dari luar (sejawat atau pakar). Dengan kehadiran orang lain dalam penelitian ini, PTK yang dilaksanakan menjadi bersifat kolaboratif. Hanya saja pengamat luar tidak boleh terlibat terlalu dalam dan mengintervensi terhadap pengambilan keputusan tindakan yang dilakukan oleh peneliti.

Terdapat empat metode observasi, yaitu observasi terbuka; observasi terfokus; observasi terstruktur dan dan observasi sistematis. Beberapa prinsip yang harus dipenuhi dalam observasi, diantaranya: (a) ada perencanaan antara dosen/guru dengan pengamat; (b) fokus observasi harus ditetapkan bersama; (c) dosen/guru dan pengamat membangun kriteria bersama; (d) pengamat memiliki keterampilan mengamati; dan (e) balikan hasil pengamatan diberikan dengan segera. Adapun keterampilan yang harus dimiliki pengamat diantaranya: (a) menghindari kecenderungan untuk membuat 
CENDEKIA, Vol. 11, No. 2, Oktober 2017

p ISSN: 1978 2098; e ISSN: 2407 8557

Http://cendekia.pusatbahasa.or.id; Email: cendekiaoslo@gmail.com Center of Language and Culture Studies, Surakarta, Indonesia

Yunastutik, Games. 2017. Peningkatan Prestasi Belajar Matematika Melalui Pembelajaran Behavioristik pada Siswa SMPN 1 Karangploso.

Cendekia, (2017), 11(2): 207 220.

penafsiran; (b) adanya keterlibatan keterampilan antar pribadi; (c) merencanakan skedul aktivitas kelas; (d) umpan balik tidak lebih dari 24 jam; (d) catatan harus teliti dan sistematis.

Dalam pembelajaran kooperatif ini terdapat enam langkah utama/tahapan. Keenam tahapan pembelajaran kooperatif tersebut dirangkum dalam tabel 3.

Tabel 3. Tahapan pembelajaran kooperatif.

\begin{tabular}{|l|l|}
\hline \multicolumn{1}{|c|}{ Fase } & \multicolumn{1}{|c|}{ Tingkah laku Peneliti } \\
\hline $\begin{array}{l}\text { Fase 1 } \\
\text { dan memampaikan tujuan } \\
\text { Fase 2 } \\
\text { Menyajikan informasi }\end{array}$ & $\begin{array}{l}\text { Peneliti menyampaikan semua tujuan } \\
\text { pembelajaran yang ingin dicapai dengan } \\
\text { memotivasi belajar siswa }\end{array}$ \\
\hline $\begin{array}{l}\text { Fase 3 } \\
\text { Mengorganisasi siswa ke } \\
\text { dalam kelompok belajar } \\
\text { dengan cara demonstrasi atau lewat bacaan }\end{array}$ & $\begin{array}{l}\text { Peneliti menjelaskan kepada siswa bagaimana } \\
\text { caranya membentuk kelompok belajar dan } \\
\text { membantu setiap kelompok agar melakukan } \\
\text { transisi secara efisien }\end{array}$ \\
\hline $\begin{array}{l}\text { Fase 4 } \\
\text { Membimbing kelompok } \\
\text { bekerja dan belajar }\end{array}$ & $\begin{array}{l}\text { Peneliti membimbing kelompok-kelompok } \\
\text { belajar pada saat mereka mengerjakan tugas } \\
\text { mereka }\end{array}$ \\
\hline $\begin{array}{l}\text { Fase 5 } \\
\text { Evaluasi }\end{array}$ & $\begin{array}{l}\text { Peneliti mengevaluasi hasil belajar tentang } \\
\text { materi yang telah dibahas atau setiap } \\
\text { kelompok memaparkan hasil kerjanya }\end{array}$ \\
\hline $\begin{array}{l}\text { Fase 6 } \\
\text { Memberikan } \\
\text { penghargaan }\end{array}$ & $\begin{array}{l}\text { Peneliti mencari cara-cara untuk menghargai } \\
\text { baik upaya maupun hasil belajar dari kelompok }\end{array}$ \\
\hline
\end{tabular}

\section{Refleksi Terhadap Tindakan}

Tahapan ini merupakan tahapan untuk memproses data yang didapat saat dilakukan pengamatan. Data yang didapat kemudian ditafsirkan dan dicari eksplanasinya, dianalisis, dan disintesis. Dalam proses pengkajian data ini dimungkinkan untuk melibatkan orang luar sebagai kolaborator, seperti halnya pada saat observasi. Keterlebatan kolaborator sekedar untuk membantu peneliti untuk dapat lebih tajam melakukan refleksi dan evaluasi. Dalam proses refleksi ini segala pengalaman, pengetahuan, dan teori instruksional yang dikuasai dan relevan dengan tindakan kelas yang dilaksanakan sebelumnya, menjadi bahan pertimbangan dan perbandingan sehingga dapat ditarik suatu kesimpulan yang mantap dan sahih. Proses refleksi ini memegang peran yang sangat penting dalam menentukan suatu keberhasilan PTK. Dengan suatu refleksi yang tajam dan terpecaya akan didapat suatu masukan yang sangat berharga dan akurat bagi penentuan langkah tindakan selanjutnya. Refleksi yang tidak tajam akan memberikan umpan balik yang bias, yang pada akhirnya menyebabkan kegagalan suatu PTK. Tentu saja kadar ketajaman proses refleksi ini ditentukan oleh kejataman dan keragaman instrumen observasi yang dipakai sebagai upaya triangulasi 
data. Observasi yang hanya mengunakan satu instrumen saja. Akan menghasilkan data yang miskin.Adapun untuk memudahkan dalam refleksi bisa juga dimunculkan kelebihan dan kekurangan setiap tindakan dan ini dijadikan dasar perencanaan siiklus selanjutnya. Pelaksanaan refleksi diusahakan tidak boleh lebih dari 24 jam artinya begitu selesai observasi langsung diadakan refleksi bersama kolaborator.

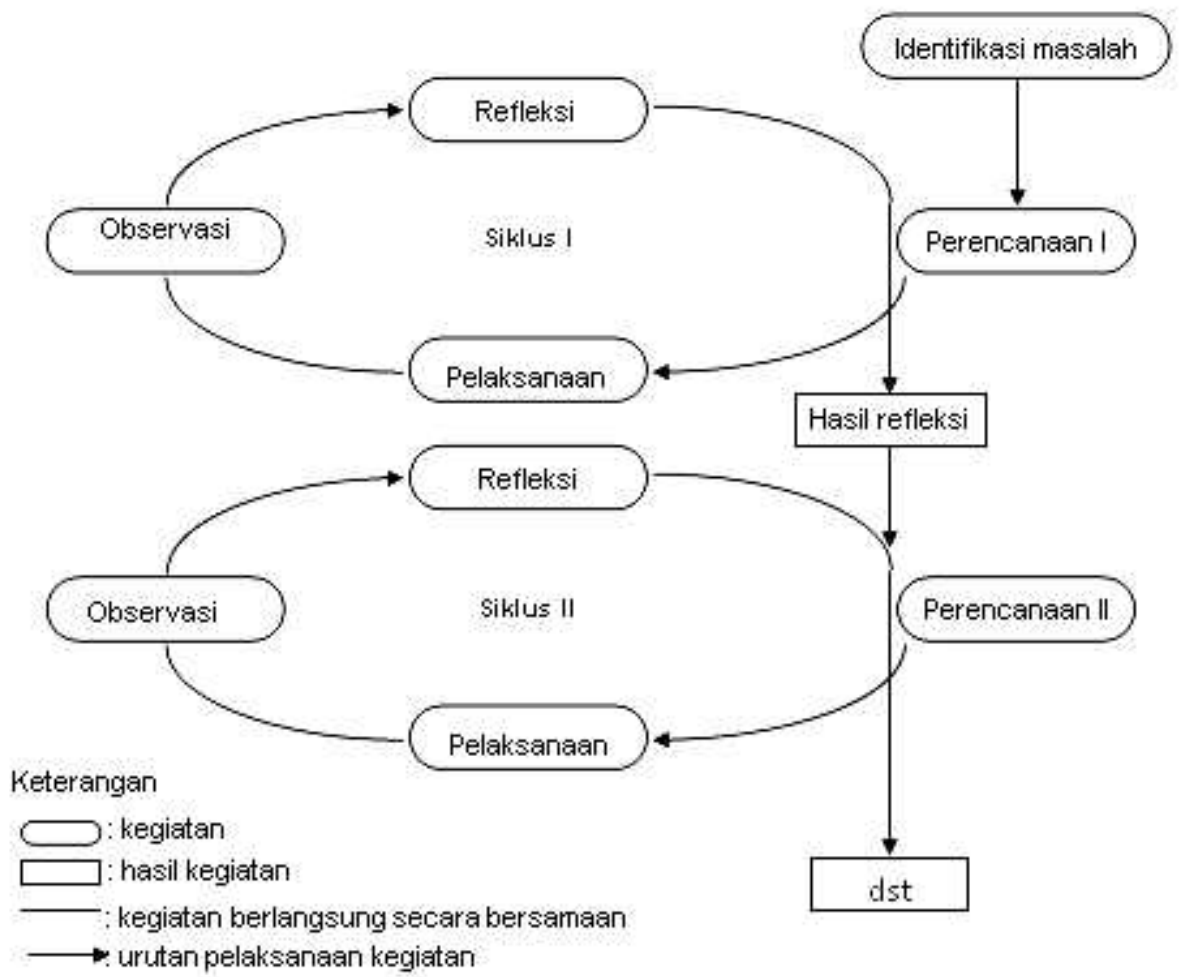

\section{HASIL DAN BAHASAN}

\section{Hasil Pembelajaran Behavioristik pada Siklus 1}

Berdasarkan data observasi pengamat pada lembar observasi kegiatan peneliti, jumlah skor yang diperoleh dari hasil pengamatan oleh pengamat adalah 25 dari skor maksimum 28. Dengan demikian, persentase skor adalah $\frac{25}{2 g} \times 100 \%=$ 89,29\%. Berdasarkan kriteria tahap keberhasilan kegiatan peneliti dalam melaksanakan kegiatan pembelajaran termasuk kategori baik sehingga dapat disimpulkan bahwa aktivitas peneliti sesuai dengan rencana yang telah ditetapkan sebelumnya.

Berdasarkan data observasi pengamat pada lembar observasi kegiatan siswa, jumiah skor yang diperoleh dari hasil pengamatan oleh pengamat adalah 26 dari 
skor maksimum 28. Dengan demikian, persentase skor adalah $\frac{26}{28}$ x $100=92,86 \%$. Berdasarkan kriteria tahap keberhasilan kegiatan siswa dalam melaksanakan kegiatan pembelajaran termasuk kategori baik sehingga dapat disimpulkan bahwa aktivitas siswa sudah sesuai dengan rencana yang telah ditetapkan oleh peneliti sebelumnya.

Hasil tes akhir siklus I untuk seluruh siswa mencapai 83,02. Ketuntasan belajar yang dapat dicapai dengan menggunakan SKM (SKM = 70) diperoleh sebanyak 38 siswa (dari total jumlah siswa satu kelas 39 siswa) atau sebesar 97,43\% siswa yang mencapai SKM., sedangkan ketuntasan klasikal dengan landasan minimal 95\% dalam kelas, dalam hal ini sudah tuntas karena 97,43\% siswa yang mencapai SKM. Periksa tabel 4.

\section{Tabel 4 Perbandingan rata-rata antara prestasi awal dengan prestasi siklus I}

\begin{tabular}{|l|c|c|}
\hline & Prestasi Awal & Siklus I \\
\hline Nilai rata - rata, & 82,05 & 83,02 \\
\hline SKM (Standart Kelulusan Minimal) & 38 siswa & 38 siswa \\
\hline Ketuntasan klasikal 95\% & $97,43 \%$ & $97,43 \%$ \\
\hline Jumlah siswa & 39 siswa & 39 siswa \\
\hline
\end{tabular}

\section{Hasil Pembelajaran Behavioristik pada Siklus 2}

Berdasarkan data observasi pengamat pada lembar observasi kegiatan peneliti, jumlah skor yang diperoleh dari hasil pengamatan oleh pengamat adalah 26 dari skor maksimum 28. Dengan demikian, persentase skor adalah $\frac{26}{28} \mathrm{x}$ $100=92,86 \%$. Berdasarkan kriteria tahap keberhasilan kegiatan peneliti dalam melaksanakan kegiatan pembelajaran termasuk kategori baik sehingga dapat disimpulkan bahwa aktivitas peneliti sudah sesuai dengan rencana yang telah ditetapkan sebelumnya.

Berdasarkan data observasi pengamat pada lembar observasi kegiatan siswa, jumlah skor yang diperoleh dari hasil pengamatan adalah 27 dari skor maksimum 28. Dengan demikian, persentase skor adalah $\frac{27}{28} \times 100=96,43 \%$. Berdasarkan kriteria tahap keberhasilan kegiatan siswa dalam melaksanakan kegiatan pembelajaran termasuk kategori sangat baik sehingga dapat disimpulkan bahwa aktivitas siswa sudah sesuai dengan rencana yang telah ditetapkan oleh peneliti sebelumnya. Sebagaimana hasil penelitian Nahar (2016) yang menyebutkan bahwa fokus utama dalam teori belajar behavioristik adalah perilaku yang terlihat dan penyebab luar yang menstimulasinya. Belajar adalah perubahan tingkah laku sebagai hasil dari pengalaman. 
Http://cendekia.pusatbahasa.or.id; Email: cendekiaoslo@gmail.com Center of Language and Culture Studies, Surakarta, Indonesia

Hasil tes akhir siklus II untuk seluruh siswa berdasarkan SKM dan ketuntasan klasikal 95\% sudah sempuma (semua siswa sudah mencapai SKM). Ini menunjukkan bahwa seluruh siswa telah mencapai prestasi yang bagus. Dengan demikian, tindakan untuk memberikan pembelajaran behaviouristik telah tercapai sempurna pada siklus II sehingga pembelajaran behaviouristik dapat meningkatkan prestasi belajar siswa kelas VII D SMPN 1 Karangploso.

Tabel 5 Perbandingan rata-rata antara prestasi awal, prestasi siklus I, dan prestasi siklus II

Tabel 5 menunjukkan rerata nilai awal dan dalam siklus.

Tabel 5. Perbandingan nilai rerata antarsiklus.

\begin{tabular}{|l|c|c|c|}
\hline & Prestasi Awal & Siklus I & Siklus II \\
\hline Nilai rata -rata & 82,05 & 83,02 & 86,00 \\
\hline SKM (Standart Kelulusan Minimal) & 38 siswa & 38 siswa & 39 siswa \\
\hline Ketuntasan klasikal 95 \% & $97,43 \%$ & $97,43 \%$ & $100 \%$ \\
\hline Jumlah siswa & 39 siswa & 39 siswa & 39 iswa \\
\hline
\end{tabular}

Peningkatan prestasi siswa tersebut dikarenakan adanya perbaikanperbaikan yang dilakukan oleh peneliti dari siklus ke siklus. Peneliti menggunakan beragam media pembelajaran, alat peraga, dan video. Sebagaimana pendapat Sugandi (2007:35) menyatakan bahwa penerapan teori behavioristik dalam kegiatan pembelajaran tergantung dari beberapa komponen seperti: tujuan pembelajaran, materi pelajaran, karakteristik siswa, media, fasilitas pembelajaran, lingkungan, dan penguatan. Berdasarkan uraian tersebut, dapat disimpulkan bahwa pembelajaran behaviouristik dapat meningkatkan prestasi belajar siswa kelas VII D SMPN 1 Karangploso. Untuk mencapai prestasi yang terus meningkat, sebaiknya pelaksanaan pembelajaran dengan pendekatan kontekstual ini harus terstruktur dan sistematis, serta keaktifan siswa sangatlah dibutuhkan dalarn pembelajaran behaviouristik. Oleh karena itu, peneliti harus bekerja keras untuk membimbing, memotivasi siswa serta melaksanakan multifungsionalnya sebagai peneliti agar siswa bisa aktif dan antusias mengikutinya. 


\section{Grafik 1 Perkembangan Hasil Belajar Prasiklus, Siklus 1, Siklus 2}

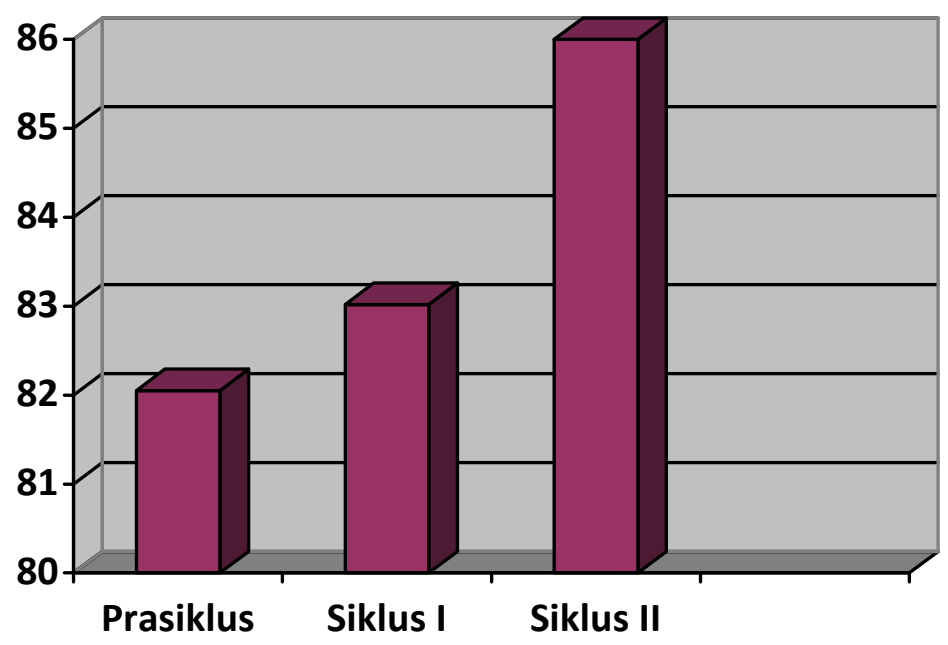

Berdasarkan grafik tersebut terdapat peningkatan hasil belajar siswa. Prasiklus menunjukkan hasil siswa mencapai 82. Siklus I terdapat peningkatan 1 poin mencapai 83. Sementara itu, pada Siklus II nilai siswa mencapai 86 atau mencapai peningkatan yang signifikan yaitu 3 poin. Ini berarti ketercapaian proses pembelajaran Matematika menggunakan pembelajaran behavioristik tergolong baik karena mencapai hasil $\geq 75 \%$. Sebagaimana pendapat Mukinan (1997:23) prinsip tersebut pembelajaran behavioristik meliputi (1) teori belajar behavioristik beranggapan yang dinamakan belajar adalah perubahan tingkah laku. Seseorang dikatakan telah belajar jika yang bersangkutan dapat menunjukkan perubahan tingkah laku, (2) teori ini beranggapan yang terpenting dalam belajar adalah adanya stimulus dan respons karena hal ini yang dapat diamati, sedangkan apa yang terjadi dianggap tidak penting karena tidak dapat diamati, dan (3) penguatan, yakni apa saja yang dapat menguatkan timbulnya respons, merupakan faktor penting dalam belajar.

Setelah melalui dua siklus pembelajaran, ditemukan beberapa hasil adalah sebagai berikut.

1. Peneliti umumnya lebih banyak mengajukan masalah kontekstual untukmenjelaskan materi dan disambut baik oleh siswa.

2. Seluruh siswa tampak semangat dalam pembelajaran terutama jika menaeriakan soal secara berkelompok.

3. Peneliti memberikan respon positif terhadap hasil presentasi siswa di depan kelas dan memberikan kesempatan kepada siswa kelompok lain untuk menanggapi penyelesaian dari kelompok yang ada di depan kelas.

4. Siswa yang aktif terlihat lebih banyak.

5. Tes di akhir pembelajaran dapat dikerjakan dengan baik oleh siswa.

6. Skor yang diperoleh siswa pads tes akhir pembelajaran $\geq 75$. 
CENDEKIA, Vol. 11, No. 2, Oktober 2017

p ISSN: 1978 2098; e ISSN: 2407 8557

Http://cendekia.pusatbahasa.or.id; Email: cendekiaoslo@gmail.com

Center of Language and Culture Studies, Surakarta, Indonesia

Yunastutik, Games. 2017. Peningkatan Prestasi Belajar Matematika Melalui

Pembelajaran Behavioristik pada Siswa SMPN 1 Karangploso.

Cendekia, (2017), 11(2): 207 220.

\section{SIMPULAN}

Berdasarkan hasil penelitian dan pembahasan berjudul "Peningkatan Prestasi Belajar Mata Pelajaran Matematika Menggunakan Pembelajaran Behavioristik pada Siswa Kelas VII SMP Negeri 1 Karangploso" dapat diambil kesimpulan antara lain penggunaan pembelajaran behavioristik dapat meningkatkan hasil belajar siswa. Prasiklus menunjukkan hasil siswa mencapai 82. Siklus I terdapat peningkatan 1 poin mencapai 83. Sementara itu, pada Siklus II nilai siswa mencapai 86 atau mencapai peningkatan yang signifikan yaitu 3 poin. Ini berarti ketercapaian proses pembelajaran Matematika menggunakan pembelajaran behavioristik tergolong baik karena mencapai hasil $\geq 75 \%$. Hasil tes akhir siklus II untuk seluruh siswa berdasarkan SKM dan ketuntasan klasikal 95\% sudah sempuma (semua siswa sudah mencapai SKM). Ini menunjukkan bahwa seluruh siswa telah mencapai prestasi yang bagus. Dengan demikian, tindakan untuk memberikan pembelajaran behaviouristik telah tercapai sempurna pada siklus II sehingga pembelajaran behaviouristik dapat meningkatkan prestasi belajar siswa kelas VII D SMPN 1 Karangploso.

\section{SARAN}

Berdasarkan pengamatan peneliti selama melakukan penelitian tindakan kelas pada kelas VII SMPN 1 Karangploso, peneliti menyarankan beberapa hal yaitu (1) pembelajaran behavioristik perlu dilaksanakan guru kelas VII SMPN 1 Karangploso, khususnya dan pada guru di sekolah lain pada umumnya. Hal ini dikarenakan pembelajaran behavioristik mengacu stimulus dan respon sehingga siswa terpacu untuk mendapatkan reward terhadap hasil yang dicapai; (2) pembelajaran behavioristik perlu dilaksanakan pada pembelajaran Matematika ataupun mata pelajaran yang lain; (3) sebagai seorang pendidik hendaknya dapat memilih model pembelajaran yang cocok untuk dipakai dalam menyampaikan materi pelajaran.

\section{DAFTAR RUJUKAN}

Arikunto, Suharsimi. 2006. Prosedur Penelitian Suatu Pendekatan Praktik. Jakarta: Rineka Cipta.

Astuti, Nofi Aji. 2011. Implementasi Behavioristik dalam Pembelajaran Menulis Karangan Narasi SMP Negeri 1 Taman Kabupaten Pemalang. Skripsi. Jurusan Bahasa dan Sastra Jawa, Fakultas Bahasa dan Seni, Universitas Negeri Semarang. (Online) http://lib.unnes.ac.id/3969/1/7605.pdf

Budiyono. 1997. Hubungan Antara Perilaku dengan Lingkungan. Jurnal Ilmu Pendidikan. Tahun IX. Nomor 2. Hlm. 23. Semarang: FIP IKIP Semarang.

Dalyono. 2009. Psikologi Pendidikan. Jakarta: Rineka Cipta.

Djamarah, Syaiful Bahri dan Aswan Zain. 2006. Strategi Belajar Mengajar. Jakarta: Rineka Cipta.

Mukinan. 1997. Teori Belajar dan Pembelajaran. Yogyakarta: P3G IKIP. 
CENDEKIA, Vol. 11, No. 2, Oktober 2017

p ISSN: 1978 2098; e ISSN: 2407 8557

Http://cendekia.pusatbahasa.or.id; Email: cendekiaoslo@gmail.com Center of Language and Culture Studies, Surakarta, Indonesia

Yunastutik, Games. 2017. Peningkatan Prestasi Belajar Matematika Melalui Pembelajaran Behavioristik pada Siswa SMPN 1 Karangploso.

Cendekia, (2017), 11(2): 207 220.

Nahar, Novi Irwan. 2016. Penerapan Teori Belajar Behavioristik dalam Proses

Pembelajaran. (Online) jurnal.um-

tapsel.ac.id/index.php/nusantara/article/download/.../94

Sugandi, Ahmad. 2007. Teori Pembelajaran. Semarang: UPT MKK UNNES.

Suryabrata, Sumadi. 2002. Psikologi Pendidikan. Jakarta: PT Raja Grafindo Persada.

Uno, Hamzah B. 2006A. Perencanaan Pembelajaran. Jakarta: PT Bumi Aksara.

----. 2006B. Orientasi Baru dalam Psikologi Pembelajaran. Jakarta: PT Bumi Aksara.

Winkel. 1984. Psikologi Pendidikan dan Evaluasi Belajar. Jakarta: Gramedia.

http://lpmpjogja.org/wp-content/uploads/2015/02/Penelitian-Tindakan-Kelas-PTK-

legiman.pdf 